\title{
Intake, nutrient digestibility, and growth performance of Holstein dairy calves consuming a milk replacer at moderate or high feeding rates
}

\author{
W. Hu, ${ }^{*}$ T. M. Hill, T. S. Dennis, F. X. Suarez-Mena, J. D. Quigley, and R. L. Schlotterbeck \\ Nurture Research Center, Provimi, Cargill Animal Nutrition, Brookville, OH 45309
}

\section{ABSTRACT}

The objective of this study was to evaluate nutrient intake and digestibility, and growth performance of calves when fed a milk replacer (MR) at 2 feeding rates. Male Holstein calves $[\mathrm{n}=49 ; 45.0 \pm 5.2$ (mean $\pm \mathrm{SD}) \mathrm{kg}$ of body weight (BW); 3 to $4 \mathrm{~d}$ of age] were randomly assigned to 1 of $2 \mathrm{MR}$ [27\% crude protein (CP), $18 \%$ fat, dry matter (DM) basis; $14 \%$ solid] feeding programs: (1) $0.66 \mathrm{~kg}$ of DM/d for first $39 \mathrm{~d}$ divided into 2 equal a.m. and p.m. meals followed by one-half of the allotment per day for $3 \mathrm{~d}$ fed in the a.m. feeding only (moderate); (2) $0.96 \mathrm{~kg}$ of DM/d for the first 42 $\mathrm{d}$ divided into 2 equal a.m. and p.m. meals followed by one-half of the allotment per day for $7 \mathrm{~d}$ fed in the a.m. feeding only (high). A textured starter fed to calves contained whole grains with $20 \% \mathrm{CP}$ and $44 \%$ starch (DM basis). At d 56, calves were moved into groups by treatment ( 4 calves/pen) and fed the same starter blended with $5 \%$ hay until d 112. Data were analyzed as a completely randomized design, or as a completely randomized design with repeated measures when applicable. Over the entire nursery period (d $0-56)$, there were no differences in average daily gain (0.63 vs. 0.64 $\mathrm{kg} / \mathrm{d}$ ) and hip width change (4.44 vs. $4.57 \mathrm{~cm}$ ) for moderate- versus high-fed calves. Apparent digestibility of DM (76.5 vs. $70.3 \%$ ), organic matter (77.4 vs. $71.2 \%$ ), CP (78.8 vs. $72.6 \%)$, and neutral detergent fiber (37.2 vs. $22.7 \%$ ) differed between moderate- and high-fed calves when estimated at d 51 to 55 . From d 56 to 112 , average daily gain (0.99 vs. $0.91 \mathrm{~kg} / \mathrm{d})$, hip width change (5.32 vs. $4.68 \mathrm{~cm})$, and gain/DM intake $(0.335$ vs. $0.307 \mathrm{~kg} / \mathrm{kg})$ were greater, but DM intake per $\mathrm{kg}$ of BW (0.028 vs. $0.028 \mathrm{~kg} / \mathrm{kg}$ ) did not differ for calves previously fed moderate versus high. Feeding calves more than $0.66 \mathrm{~kg}$ of $\mathrm{DM} / \mathrm{d}$ from a $27 \% \mathrm{CP}, 18 \%$ fat MR did not improve BW gain and structural growth in

Received January 10, 2019.

Accepted April 27, 2019.

*Corresponding author: whu@provimi-na.com the nursery period (d 0-56), and decreased these in the grower period (d 56-112) partially through reduction in digestibility of the starter.

Key words: calf, growth, digestion

\section{INTRODUCTION}

Increased consumption of milk or milk replacer (MR) by calves has been shown to improve growth rates (Diaz et al., 2001) and has potential for increasing milk production in the first lactation (Gelsinger et al., 2016). Therefore, there is an increasing interest in feeding greater amounts of milk or MR to young calves in the dairy industry. However, calves fed more milk or MR have reduced preweaning starter intake and delayed age at which notable starter intake begins; thus, delayed starter intake would slow down the process of rumen development (Terré et al., 2007; Hill et al., 2010, 2016). In contrast, calves fed lower milk or MR increase starter intake at an early age; earlier and greater starter consumption before weaning help transition smoothly from liquid to dry feed, thus avoiding disruption of nutrient intake and slumps in growth (Khan et al., 2007; Bach et al., 2013b).

Inconsistent results are found in the literature regarding the effect of varying milk or MR feeding program on the performance of calves (Omidi-Mirzaei et al., 2015). Debate on how to optimize nutrition from milk or MR feeding for dairy calves continues. Indeed, a multitude of factors such as composition of MR, quality and characteristics of starter, weaning procedure, and so on, would affect how calves respond to milk or MR in their early life (Bateman et al., 2009; Hill et al., 2009; Sweeney et al., 2010). Further research effort is needed to identify the most appropriate MR feeding program for dairy calves. In addition, properly addressing the effects of feeding program on growth performance requires an evaluation for which it is necessary to take a sufficient amount of time after weaning; however, many previous studies ended only a week to less than a month postweaning (Cowles et al., 2006; Omidi-Mirzaei et al., 2015; Rosenberger et al., 2017). The objective of this study was to evaluate nutrient intake and digestion, 
and growth performance in calves up to 4 mo of age, when fed 2 MR feeding programs.

\section{MATERIALS AND METHODS}

All animals were cared for as described in the Guide for the Care and Use of Agricultural Animals in Research and Teaching (FASS, 2010) and under approval of the institutional animal care and use committee. Male Holstein calves (50 head initially, but 1 was removed due to a severe navel infection; 3 to $4 \mathrm{~d}$ of age) were received at the Nurture Research Center nursery in southwest Ohio from a commercial dairy farm after a 3.5-h transit. The nursery included individual pens for calves in a barn with curtain sides, natural ventilation, and no added heat. Calf pens were bedded with long wheat straw. The day after arrival at approximately noon, the calves were weighed $(\mathrm{d} 0 ; 45.0 \pm 5.2 \mathrm{~kg}$ of initial BW). At this time, blood was collected by jugular venipuncture, serum was separated by centrifugation at $3,000 \times g\left(\mathrm{VWR}\right.$, Batavia, IL) at $20^{\circ} \mathrm{C}$ for 15 min, and serum protein concentration (d $0 ; 5.2 \pm 0.1$ $\mathrm{mg} / \mathrm{dL}$ ) was estimated using an optical refractometer (ATAGO U.S.A. Inc., Bellevue, WA). All calves were initially fed $681 \mathrm{~g}$ on an as-fed basis from MR for first p.m. and following a.m. feeding, then randomly assigned to 1 of 2 feeding programs: (1) $681 \mathrm{~g} / \mathrm{d}$ on an as-fed basis for first $39 \mathrm{~d}$ divided into 2 equal a.m. and p.m. meals and $340.5 \mathrm{~g} / \mathrm{d}$ for $3 \mathrm{~d}$ fed in the a.m. feeding only (moderate); (2) 1,000 g/d on an as-fed basis for the first $42 \mathrm{~d}$ divided into 2 equal a.m. and p.m. meals and $500 \mathrm{~g} / \mathrm{d}$ for $7 \mathrm{~d}$ fed in the a.m. feeding only (high). Calves were fed a common MR (27\% CP, $18 \%$ fat DM basis; $14 \%$ solids; Table 1) in equal meals at 0600 and $1530 \mathrm{~h}$. This MR was formulated with added synthetic AA (Hill et al., 2008) and fatty acids (Hill et al., 2011). Rejected MR was weighed back after each feeding. A whole-grain, textured calf starter $(20 \% \mathrm{CP}$, $44 \%$ starch; specific fatty acids added as in Hill et al., 2011; Table 1) and water were fed for ad libitum intake during the nursery period. Every other bag of MR and calf starter was sampled and composited for nutrient analysis. Calves were observed for periods of $5 \mathrm{~s}$ or more by an experienced technician at least 8 times per day between 0600 and $1700 \mathrm{~h}$, including immediately after feeding MR and starter. Feces were scored daily using a 1 to 5 scale with 1 being normal and 5 being watery (modified from Kertz and Chester-Jones, 2004). Fecal score $\geq 3$ was considered abnormal, day with abnormal fecal score was counted as abnormal fecal day. Antibiotic medical treatment was based on a binomial scoring system of lethargy, coughing, nasal discharges, or rectal temperatures $>39.4^{\circ} \mathrm{C}$. Calves with fecal scores $>2$ received oral electrolytes but these were not counted as medical treatments. Medical treatments were recorded daily; day with medical treatment was counted as medical day. Calves were weighed weekly and hip widths were measured on d 0 and every 2 wk thereafter.

Five calves/treatment were randomly selected for use to estimate nutrient digestibility postweaning (d 51 to $55)$. Twelve fecal grab samples per calf were collected via rectal palpation by hand to account for 2-h intervals $(0200,0400,0600 \mathrm{~h}$, and so on) of the 24 -h day by rotating sampling times over the 5-d collection period. The fecal samples were frozen daily upon collection, combined on an equal wet weight basis, and subsampled for chemical analysis to estimate total-tract nutrient digestibility (Hill et al., 2016). Acid-insoluble ash was used as an internal marker. The nursery pens were bedded with long wheat straw and straw consumption by calves was possible (Hill et al., 2010, 2016). This was accounted for by not adding new bedding $3 \mathrm{~d}$ before and during fecal collection periods to minimize the

Table 1. Nutrient composition of milk replacer, starter, and hay

\begin{tabular}{|c|c|c|c|c|}
\hline \multirow[b]{2}{*}{ Nutrient $^{1}$} & \multicolumn{2}{|c|}{ Nursery } & \multicolumn{2}{|c|}{ Grower } \\
\hline & Milk replacer ${ }^{2}$ & Starter $^{3}$ & Starter & Hay \\
\hline DM, $\%$ as fed & 96.4 & 88.3 & 87.4 & 87.0 \\
\hline $\mathrm{CP}$ & 27.6 & 20.6 & 20.8 & 6.1 \\
\hline $\mathrm{ADF}$ & - & 7.7 & 6.6 & 32.9 \\
\hline NDF & - & 14.5 & 16.1 & 59.5 \\
\hline Sugar & - & 6.0 & 5.6 & 5.1 \\
\hline Starch & - & 43.9 & 42.1 & 0.8 \\
\hline Fat & 18.3 & 4.2 & 4.3 & 2.4 \\
\hline Ash & 6.1 & 6.8 & 6.5 & 6.1 \\
\hline $\mathrm{ME},{ }^{4} \mathrm{Mcal} / \mathrm{kg}$ & 4.7 & 3.1 & 3.1 & 2.3 \\
\hline
\end{tabular}


chance of straw intake during the week of digestibility measurements.

On d 56, calves from the nursery period were grouped by preweaning treatment and moved to pens (4 calves/ pen within treatment, except for 1 pen of 5 calves) until $112 \mathrm{~d}$ of age. The pens had $6.5 \mathrm{~m}^{2}$ of outside pen space and $1.35 \mathrm{~m}^{2}$ of inside pen space per calf bedded with wheat straw. Calf starter used in the nursery period was blended with $5 \%$ chopped grass hay (approximately $2.5 \mathrm{~cm}$ long) on an as-fed basis and fed for ad libitum intake with free-choice access to water. Grower feed refusals were weighed daily to determine DMI. Every other bag of starter and every bale of hay was sampled and composited for nutrient analysis. Calf BW and hip width were determined on d 56, 84, and 112 .

Composites of feeds, refusals, and feces were analyzed (AOAC International, 2000) for DM (oven method 930.15), ash (oven method 942.05), CP (Kjeldahl method 988.05), fat (alkaline treatment with RoeseGottlieb method 932.06 for MR; diethyl ether extraction method 2003.05 for starters and hay), NDF with ash by the procedure of Van Soest et al. (1991) without sodium sulfite or $\alpha$-amylase, ADF with ash (Robertson and Van Soest, 1981), starch ( $\alpha$-amylase method; Hall, 2009), sugar (colorimetric method; Dubois et al., 1956), and acid insoluble ash (Van Keulen and Young, 1977).

The average temperature for the 56-d nursery period was $7^{\circ} \mathrm{C}$ with a range from -11 to $30^{\circ} \mathrm{C}$. The average relative humidity was $55 \%$ with a range from 18 to $100 \%$. The average temperature for the 56 -d grower period was $16^{\circ} \mathrm{C}$ (ranged from -5 to $31^{\circ} \mathrm{C}$ ) and the average humidity was $69 \%$ with a range from 28 to $100 \%$.

In the nursery period, data of daily intakes were reduced to weekly means for each calf. In the grower period, data of daily intakes were reduced to means in 28-d periods for each pen of calves. Average BW (i.e., mean of beginning and final BW) within a week was calculated; ADG within a week was also calculated as the difference between initial and final BW divided by $7 \mathrm{~d}$. Thus, weekly DMI or nutrient intakes per $\mathrm{kg}$ of $\mathrm{BW}$ for each calf were calculated as weekly DMI or nutrient intakes divided by average BW within a week, whereas BW on daily basis was estimated based on initial BW and ADG within a week, DMI or nutrient intakes per $\mathrm{kg}$ of $\mathrm{BW}$ for each individual calf was then calculated as daily DMI or nutrient intakes divided by the estimated daily BW. The potential effect of initial BW on the primary outcome measures was examined to determine whether initial BW should be used as a covariate in the models. The initial BW were not included in the statistical models as covariates. All data were analyzed as a completely randomized design, or when applicable a completely randomized design with repeated measures in a week, or in 14- or 28-d periods, using MIXED procedures (SAS Institute Inc., 2012). Calf in the nursery period and pen in the grower period were the experimental units. In the mixed models with repeated measurements, calf or pen was treated as a random variable and the first-order autoregressive structure was selected as the appropriate covariance structure based on Akaike's information criterion. Significance was defined as $P \leq 0.05$, whereas $0.05<$ $P \leq 0.10$ was considered to indicate a trend toward a significant effect.

\section{RESULTS}

A difference of initial BW occurred in 2 MR treatments (moderate, $42.7 \mathrm{~kg}$ vs. high, $47.2 \mathrm{~kg} ; P=0.001$; Table 2). To minimize the effect of initial BW before MR treatments assigned, DMI or nutrient intakes for each individual calf were subjected to BW adjustment and reported on a per BW basis. Correlation and homogeneity of regression slopes tests were conducted. It was shown that no significant relationships occurred between initial BW and the primary outcome measures. Thus, initial BW would not be used as a covariate for statistical analysis.

In the first $5 \mathrm{~d}$, a difference $(<2 \%)$ was observed between the amount of MR allocated and the amount of MR consumed in high-fed calves, but not in moderate-fed calves. All allotted MR was consumed for both groups of calves thereafter. No differences of abnormal fecal day (0.11 vs. $0.13 \mathrm{~d} / \mathrm{wk}, P=0.651$ ) and medical day (0.14 vs. $0.17 \mathrm{~d} / \mathrm{wk} ; P=0.507)$ were observed in moderate- versus high-fed calves (Table 2).

\section{Nutrient Intake}

During the first 21-d preweaning period, high-fed calves had greater intakes $(P<0.001)$ of total DM, ME, CP, apparently digestible protein (ADP), and fat, but less intakes of starter $(P=0.010)$ and NDF $(P$ $=0.010 ;$ Table 2$)$. However, over the entire nursery period $(0-56 \mathrm{~d})$, it was found that the total DMI was similar (21.26 vs. $21.41 \mathrm{~g} / \mathrm{d}$ per $\mathrm{kg}$ of $\mathrm{BW} ; P=0.803$ ) in high- versus moderate-fed calves. Nevertheless, the evolution of nutrient intakes as feeding day progressed was different between $2 \mathrm{MR}$ feeding rates (Figure 1). Starter intake was low and remained similar until d 16 in high- or moderate-fed calves. From d 17 to the end of nursery period, moderate-fed calves had greater starter intake $(P<0.05)$ in each day compared with high-fed calves. During early preweaning period, because of small amounts of starter intake in all calves and more MR being offered to high-fed calves, it was anticipated that high-fed calves had higher DMI compared with moderate-fed calves; however, such higher 
level of DMI in high- versus moderate-fed calves $(P<$ 0.05 ) remained only until d 20. From d 21 to 42, similar DMI occurred between 2 MR feeding rates except for the lower DMI of moderate-fed calves at d 40, likely due to the MR reduction in the first day of weaning. Thereafter, greater DMI always occurred in moderateversus high-fed calves $(P<0.05$; Figure 1$)$.

Although moderate-fed calves consumed similar amounts of total DM as did high-fed calves at d 21, the greater starter intake in moderate-fed calves was not enough to compensate the nutrients for the reduced MR intake as the experiment designed, thus the intakes of $\mathrm{ME}, \mathrm{CP}$ and ADP remained lower compared with those of high-fed calves (Figure 1). With increasing starter intake, moderate-fed calves had more intakes of ME, CP, and ADP, reaching the similar levels of those nutrients for high-fed calves, at d 29, 28, and 32 , respectively. From then on, the intakes of ME, CP, and ADP did not differ between $2 \mathrm{MR}$ feeding rates until d 39. When weaning started in d 40 to 42 for moderate-fed calves, the reduction of MR intake as result of weaning caused drops in intakes of ME, CP, and ADP. However, the intakes of ME, CP, and ADP for moderate-fed calves bounced back quickly, reaching to and then persisting with the similar levels of those nutrients in high-fed calves for as long as 3 to $4 \mathrm{~d}$, and were higher thereafter $(P<0.05$; except ADP in d 49) until the end of the nursery period (Figure 1).

\section{Apparent Nutrient Digestibility}

Apparent nutrient digestibility was evaluated after weaning in the nursery period (d 51 to 55 ; Table 3 ). The digestibility of $\mathrm{DM}(76.5$ vs. $70.3 \% ; P=0.006)$, OM (77.4 vs. $71.2 \% ; P=0.007)$, $\mathrm{CP}$ (78.8 vs. $72.6 \%$; $P=0.001)$, and NDF (37.2 vs. $22.7 ; P=0.009)$ was

Table 2. Performance of calves fed moderate or high rates of milk replacer in the nursery period

\begin{tabular}{|c|c|c|c|c|}
\hline \multirow[b]{2}{*}{ Item } & \multicolumn{2}{|c|}{ Milk replacer ${ }^{1}$} & \multirow[b]{2}{*}{ SEM } & \multirow[b]{2}{*}{$P$-value } \\
\hline & Moderate & High & & \\
\hline Initial BW, kg & 42.7 & 47.2 & 0.96 & 0.001 \\
\hline $\begin{array}{l}\text { Initial serum protein, } \mathrm{mg} / \mathrm{dL} \\
\text { d } 0 \text { to } 21\end{array}$ & 5.4 & 5.0 & 0.12 & 0.023 \\
\hline $\mathrm{ADG}, \mathrm{kg} / \mathrm{d}$ & 0.34 & 0.42 & 0.026 & 0.018 \\
\hline \multicolumn{5}{|l|}{ Intake per $\mathrm{kg}$ of $\mathrm{BW}$} \\
\hline Starter, g/d & 2.33 & 1.36 & 0.256 & 0.010 \\
\hline $\mathrm{CP}, \mathrm{g} / \mathrm{d}$ & 4.53 & 5.52 & 0.096 & $<0.001$ \\
\hline $\mathrm{ADP}^{2} \mathrm{~g} / \mathrm{d}$ & 4.12 & 5.08 & 0.085 & $<0.001$ \\
\hline $\mathrm{ME}, \mathrm{kcal} / \mathrm{d}$ & 78.0 & 95.5 & 1.63 & $<0.001$ \\
\hline Fat, $\mathrm{g} / \mathrm{d}$ & 2.78 & 3.52 & 0.060 & $<0.001$ \\
\hline $\mathrm{NDF}, \mathrm{g} / \mathrm{d}$ & 0.34 & 0.20 & 0.040 & 0.010 \\
\hline \multicolumn{5}{|l|}{ d 0 to 56} \\
\hline \multirow{2}{*}{\multicolumn{5}{|c|}{ Intake per $\mathrm{kg}$ of BW }} \\
\hline & & & & \\
\hline DM, g/d & 21.41 & 21.26 & 0.432 & 0.803 \\
\hline Starter, $\mathrm{g} / \mathrm{d}$ & 11.85 & 7.66 & 0.402 & $<0.001$ \\
\hline $\mathrm{CP}, \mathrm{g} / \mathrm{d}$ & 5.08 & 5.33 & 0.096 & 0.065 \\
\hline $\mathrm{ADP}, \mathrm{g} / \mathrm{d}$ & 4.28 & 4.67 & 0.078 & 0.001 \\
\hline $\mathrm{ME}, \mathrm{kcal} / \mathrm{d}$ & 85.0 & 90.5 & 1.57 & 0.015 \\
\hline Fat, g/d & 2.25 & 2.81 & 0.043 & $<0.001$ \\
\hline $\mathrm{NDF}, \mathrm{g} / \mathrm{d}$ & 1.72 & 1.11 & 0.058 & $<0.001$ \\
\hline Gain/DMI, kg/kg & 0.50 & 0.47 & 0.014 & 0.109 \\
\hline Gain/ME intake, $\mathrm{kg} / \mathrm{Mcal}$ & 0.15 & 0.12 & 0.004 & $<0.001$ \\
\hline Gain/CP intake, $\mathrm{kg} / \mathrm{kg}$ & 2.09 & 1.87 & 0.055 & 0.005 \\
\hline Gain/ADP intake, $\mathrm{kg} / \mathrm{kg}$ & 2.50 & 2.16 & 0.063 & $<0.001$ \\
\hline $\mathrm{CP} / \mathrm{ME}$ intake, $\mathrm{g} / \mathrm{Mcal}$ & 59.63 & 58.96 & 0.038 & $<0.001$ \\
\hline ADP/ME intake, $\mathrm{g} / \mathrm{Mcal}$ & 50.63 & 51.55 & 0.052 & $<0.001$ \\
\hline Hip width change, $\mathrm{cm}$ & 4.44 & 4.57 & 0.160 & 0.554 \\
\hline Abnormal fecal day, ${ }^{3} \mathrm{~d} / \mathrm{wk}$ & 0.11 & 0.13 & 0.040 & 0.651 \\
\hline Medical day, ${ }^{4} \mathrm{~d} / \mathrm{wk}$ & 0.14 & 0.17 & 0.030 & 0.507 \\
\hline
\end{tabular}


greater, but $\mathrm{ADF}(24.6$ vs. $10.5 \% ; P=0.095)$ and fat (82.0 vs. $77.2 \% ; P=0.068)$ tended to be greater for moderate- versus high-fed calves.

\section{Growth Performance}

Weekly ADG for both MR feeding rates in the nursery period, along with predicted energy-, and ADPallowable ADG based on NRC (2001) are shown in Figure 2. Moderate-fed calves had less ADG during the first $21 \mathrm{~d}$ than did high-fed calves (0.34 vs. $0.42 \mathrm{~kg} / \mathrm{d}$; $P=0.018)$. However, the overall ADG across the whole nursery period ( $\mathrm{d} 0-56)$ did not differ in moderate- ver- sus high-fed calves ( 0.63 vs. $0.64 \mathrm{~kg} / \mathrm{d} ; P=0.762$ ); the same was true for hip width change $(4.44 \mathrm{vs} .4 .57 \mathrm{~cm}$; $P=0.554)$. Moderate-fed calves had less energy- $(0.45$ vs. $0.76 \mathrm{~kg} / \mathrm{d} ; P<0.001)$ and ADP-allowable gain $(0.68$ vs. $0.99 \mathrm{~kg} / \mathrm{d} ; P<0.001)$ during the first $21 \mathrm{~d}$ than did high-fed calves (Table 4). Similarly, less energy- (0.64 vs. $0.82 \mathrm{~kg} / \mathrm{d} ; P<0.001)$ and ADP-allowable gain $(0.82$ vs. $1.02 \mathrm{~kg} / \mathrm{d} ; P<0.001$ ) was observed over the entire nursery period in moderate- versus high-fed calves. Efficiencies of ME (0.15 vs. $0.12 \mathrm{~kg}$ of BW gain per Mcal of ME; $P<0.001)$, CP (2.09 vs. $1.87 \mathrm{~kg}$ of $\mathrm{BW}$ gain per $\mathrm{kg}$ of $\mathrm{CP}$ intake; $P=0.005)$, and ADP (2.50 vs. $2.16 \mathrm{~kg}$ of BW gain per $\mathrm{kg}$ of ADP intake; $P<0.001$ ) (a)
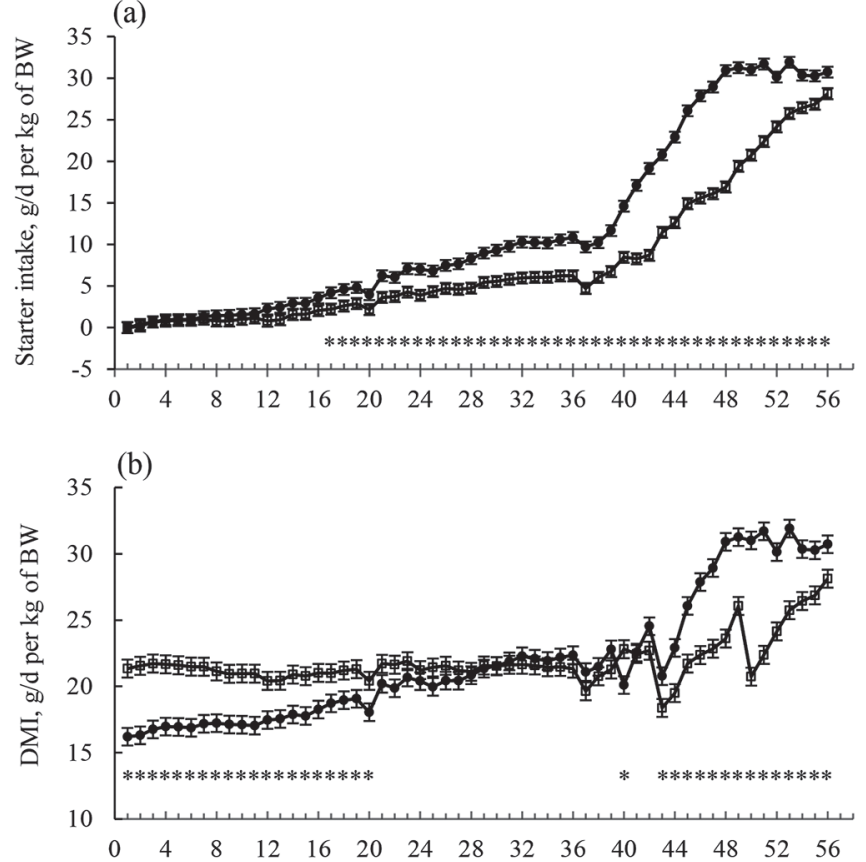

(c)

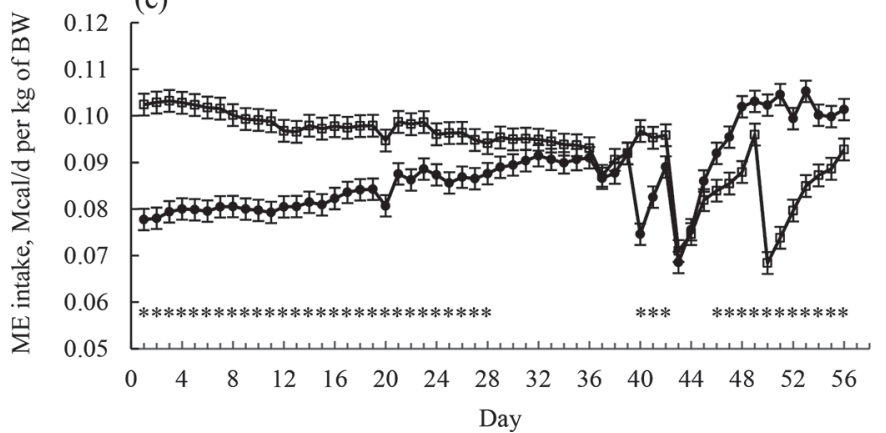

(d)

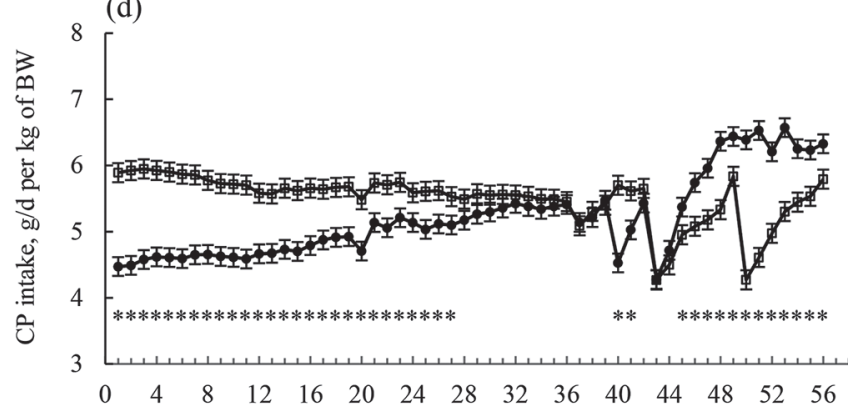

(e)

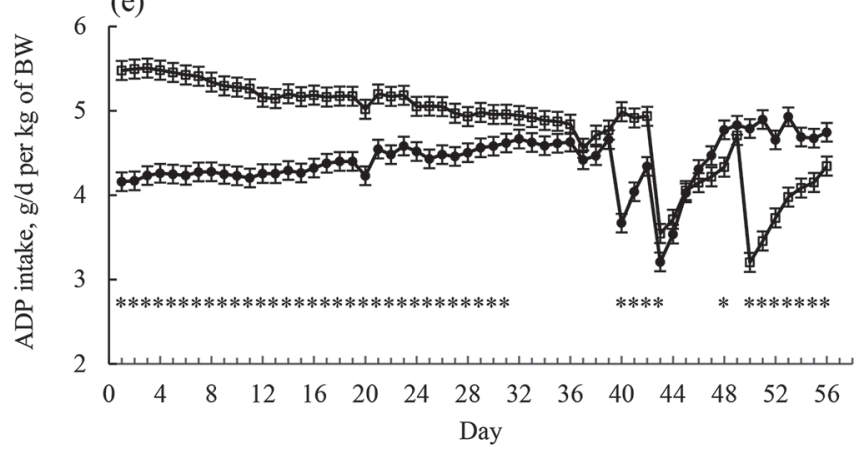

Figure 1. Intake patterns of (a) starter (g/d per kg of BW; SE =0.663), (b) DMI (g/d per kg of BW; SE = 0.677), (c) ME (Mcal/d per $\mathrm{kg}$ of $\mathrm{BW} ; \mathrm{SE}=0.002)$, (d) $\mathrm{CP}(\mathrm{g} / \mathrm{d}$ per $\mathrm{kg}$ of $\mathrm{BW} ; \mathrm{SE}=0.144)$, and (e) apparent degradable protein $(\mathrm{ADP} ; \mathrm{g} / \mathrm{d}$ per kg of BW; SE = 0.113) for Holstein calves fed moderate or high rates of milk replacer in the nursery period. Moderate: $0.66 \mathrm{~kg}$ of $\mathrm{DM} / \mathrm{d}$ for the first $39 \mathrm{~d}$ followed by one-half of the allotment for $3 \mathrm{~d}$. High: $0.96 \mathrm{~kg}$ of DM/d for the first $42 \mathrm{~d}$ followed by one-half of the allotment for $7 \mathrm{~d}$. Asterisk indicates the day when intake differed in the calves fed moderate versus high rate of milk replacer $(P<0.05)$. 
utilization were higher in moderate- versus high-fed calves (Table 2).

During the grower period (d 56-112), ADG (0.99 vs. $0.91 \mathrm{~kg} / \mathrm{d} ; P=0.011)$, BW gain per $\mathrm{kg}$ of DMI $(0.335$ vs. $0.307 \mathrm{~kg} / \mathrm{kg} ; P=0.030)$, and hip width change $(5.32$ vs. $4.68 \mathrm{~cm} ; P=0.015)$ were greater, but DMI per kilogram of BW (0.028 vs. $0.028 \mathrm{~kg} / \mathrm{kg} ; P=0.985)$ did not differ for moderate- versus high-fed calves (Table 5).

\section{DISCUSSION}

Regardless of different feeding rates of MR offered to calves, starter intake was very low for both groups of calves during the first 2 wk of age, which is in consistent with the study of Jasper and Weary (2002).

The greater MR intake obtained in high versus moderate-fed calves resulted in greater ADG in the first $21 \mathrm{~d}$ of the nursery period. During wk 4 to 5 , both high- and moderate-fed calves had greater ADG than previously; however, calves fed both MR treatments had similar ADG, likely because moderate-fed calves might be able to compensate nutrient intake by consuming more starter (Figure 2). It was suggested that an older weaning age and longer duration of weaning would improve starter intake and weight gain (Sweeney et al., 2010). In the present study, a dramatic decrease in ADG occurred during weaning transition in high-fed calves in wk 7 , but it was not true for moderate-fed calves during weaning (wk 6; Figure 2), even though high-fed calves had an older weaning age (43 vs. 40 d) and longer duration of gradual weaning ( 7 vs. 3 d) compared with moderate-fed calves. Apparently, the reduction of MR offered in either high- or moderate-fed calves during weaning decreased total nutrient intake; nevertheless, the nutrient loss caused by reduction of MR intake could be compensated rapidly by increasing starter intake. However, varying periods of time were needed to do so after disrupting by weaning process.

Table 3. Apparent digestibility of calves (5/treatment) fed moderate or high rates of milk replacer postweaning (d 51-55)

\begin{tabular}{lcccc}
\hline \multirow{2}{*}{$\begin{array}{l}\text { Digestibility, } \\
\%\end{array}$} & \multicolumn{3}{c}{ Milk replacer $^{1}$} & \\
\cline { 2 - 3 } & Moderate & High & SEM & $P$-value \\
\hline DM & 76.5 & 70.3 & 1.67 & 0.006 \\
OM & 77.4 & 71.2 & 1.70 & 0.007 \\
CP & 78.8 & 72.6 & 1.12 & 0.001 \\
ADF & 24.6 & 10.5 & 7.42 & 0.095 \\
NDF & 37.2 & 22.7 & 4.17 & 0.009 \\
Sugar & 83.4 & 86.3 & 4.14 & 0.507 \\
Starch & 94.2 & 93.2 & 2.43 & 0.683 \\
Fat & 82.0 & 77.2 & 2.29 & 0.068 \\
\hline
\end{tabular}

${ }^{1}$ Moderate: $0.66 \mathrm{~kg}$ of $\mathrm{DM} / \mathrm{d}$ for the first $39 \mathrm{~d}$ followed by one-half of the allotment for $3 \mathrm{~d}$. High: $0.96 \mathrm{~kg}$ of DM/d for the first $42 \mathrm{~d}$ followed by one-half of the allotment for $7 \mathrm{~d}$.
Calves fed high appeared to take longer time than moderate-fed calves to regain the similar intakes of ME and ADP (Figure 1) as those immediate before starting the weaning process.

Calves fed high had the advantage of greater growth rate in early preweaning period, resulting from more MR consumption; however, such advantage with greater BW gain was relatively small compared with moderatefed calves. Moreover, calves fed more MR experienced a slump of growth during weaning transition (wk 7). Thus, over the entire nursery period, no difference in BW gain and structure growth was detected in calves fed MR in either one of feeding rates. In contrast to the findings in the present study, Jasper and Weary (2002) found that growth rate preweaning in the calves fed more milk was superior, and the advantage of BW gain maintained through weaning or postweaning periods. One reason for this discrepancy could probably be attributed to the different amounts of milk or MR offered to calves or the milk or MR feeding methods. In their study (Jasper and Weary, 2002), milk amounts in the conventionally fed calves were restricted to only $10 \%$ of the calf's BW, and the milk was distributed evenly across the 2 feedings daily while ad libitum fed calves were allowed continuous access to milk before weaning.

Consistent with the previous studies (Terré et al., 2007; Hill et al., 2016), the postweaning digestibility measurements of DM, OM, ADF, and NDF were less or tended to be less for high- versus moderate-fed calves in the present study (Table 3). Moreover, a greater extent of difference of NDF and ADF digestibility was observed between $2 \mathrm{MR}$ feeding rates. The lower NDF and ADF digestibility for high- versus moderate-fed calves suggested less rumen development. By using purine excretion, an indirect measure of microbial protein flow from the rumen, to assess the extent of microbial and rumen development (Funaba et al., 1997), it was evident that purine excretion in calves fed larger amounts of MR was less than that of calves fed the low MR feeding program (1.14 vs. $1.90 \mathrm{mmol} / \mathrm{d}$ per $\mathrm{BW}^{0.75}$; Terré et al., 2006).

Dennis et al. (2018a) measured digestibility in calves fed moderate or high amounts of MR at 39, 49, and $60 \mathrm{~d}$ of age and reported that digestibility of ADF and NDF in the starter increased with age. They also reported that digestibility of ADF and NDF was less in calves fed high versus moderate amounts of MR (Dennis et al., 2018a). Thus, not only intake of starter but also digestibility of starter can be reduced when high amounts of MR (over approximately $0.66 \mathrm{~kg}$ of $\mathrm{DM}$ ) are fed, contributing to less nutrient supply for growth. In a separate study (Dennis et al., 2018b), it was found that as MR preweaning was increased incrementally over $0.66 \mathrm{~kg}$ of $\mathrm{DM} / \mathrm{d}$, postweaning digestibility of 


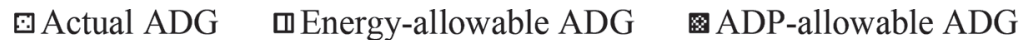

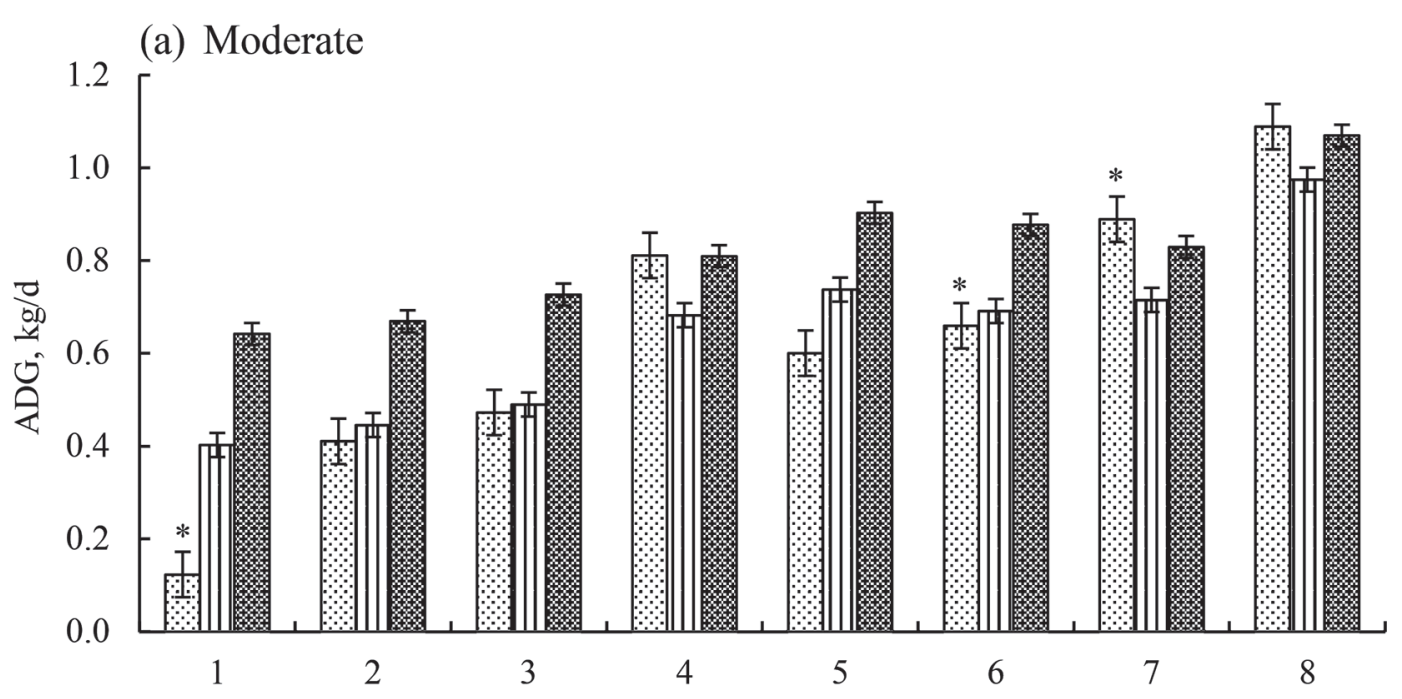

(b) High

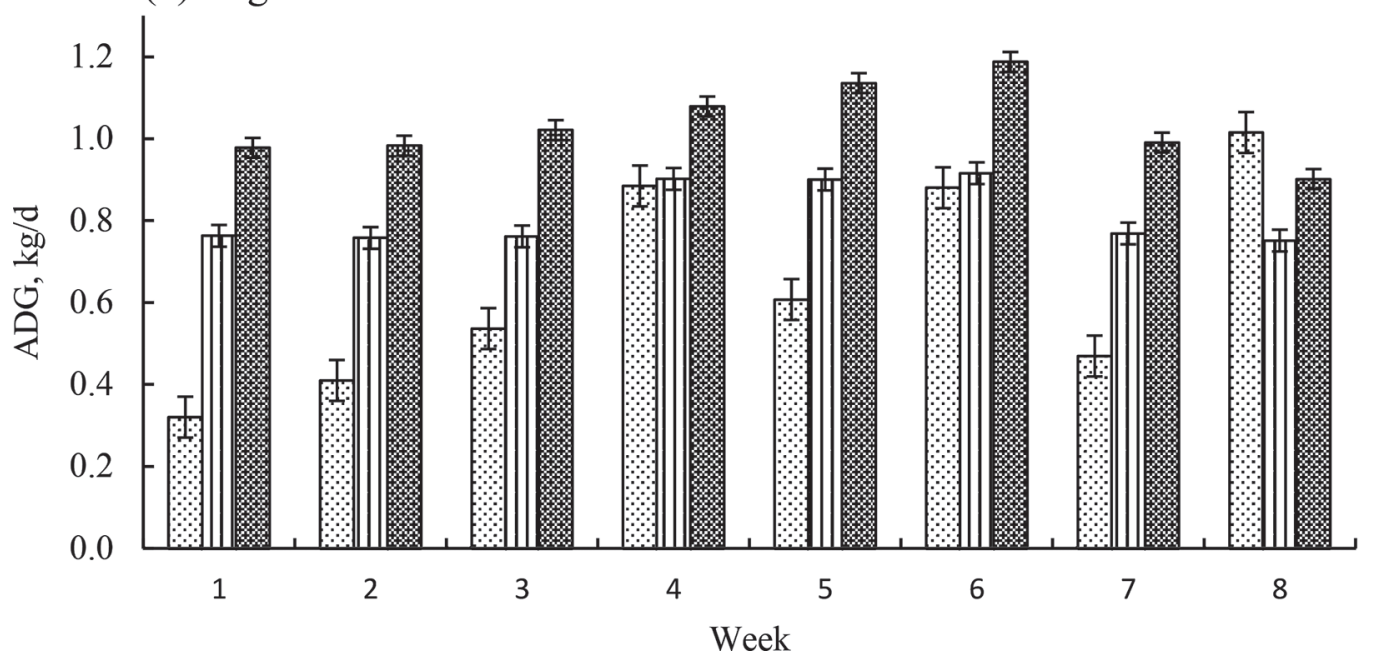

Figure 2. Actual ADG, energy-allowable ADG, and apparent digestible protein (ADP)-allowable ADG in calves fed moderate or high rates of milk replacer in the nursery period. Moderate: $0.66 \mathrm{~kg}$ of DM/d for the first $39 \mathrm{~d}$ followed by one-half of the allotment for $3 \mathrm{~d}$. High: $0.96 \mathrm{~kg}$ of DM/d for the first $42 \mathrm{~d}$ followed by one-half of the allotment for $7 \mathrm{~d}$. Energy- and ADP-allowable ADG were calculated based on NRC (2001). An asterisk indicates actual ADG at the same week differed in the calves fed moderate versus high rate of milk replacer $(P<0.05 ; \mathrm{SE}=0.050)$.

$\mathrm{ADF}, \mathrm{NDF}$, and $\mathrm{OM}$ decreased at $56 \mathrm{~d}$ and even at 70 $\mathrm{d}$ of age. This further shows how feeding high rates of MR can reduce the digestibility of the starter, reducing the nutrients available for growth into extended weeks postweaning.

Consistent with Chapman et al. (2016), starch digestibility was high (>93\%; Table 3$)$ and did not differ between $2 \mathrm{MR}$ feeding rates. It is not surprising that similar and high starch digestibility occurred between 2 MR feeding rates, since starch is highly fermentable in both the rumen and large intestine by microbes and digested in small intestine by amylolytic enzymes. In addition, the fat digestibility tended to be less for high- versus moderate-fed calves in the present study. In comparison with calves fed more MR, similar (Hill et al., 2010), less (Hill et al., 2016), or more (Chapman et al., 2016) fat digested postweaning in calves fed small amounts of MR have been reported. Contrary to the study of Hill et al. (2016), but in agreement with another study (Chapman et al., 2016), it was found that less $\mathrm{CP}$ was digested in high- versus moderate-fed calves in the present study. No explanation is readily apparent for the reason why the digestion of fat and $\mathrm{CP}$ differed in high- versus moderate-fed calves.

Over the entire nursery period, similar ADG/ME intake and $\mathrm{ADG} / \mathrm{CP}$ intake were shown in calves fed 
Table 4. Predicted energy- and apparent degradable protein (ADP)-allowable gain for calves fed moderate or high rates of milk replacer in the nursery period

\begin{tabular}{lcccc}
\hline & \multicolumn{2}{c}{ Milk replacer $^{2}$} & & \\
\cline { 2 - 2 } Item $^{1}$ & Moderate & High & SEM & $P$-value \\
\hline d 0 to 21 & & & & \\
Energy-allowable gain, kg/d & 0.45 & 0.76 & 0.014 & $<0.001$ \\
ADP-allowable gain, kg/d & 0.68 & 0.99 & 0.007 & $<0.001$ \\
Energy-allowable gain - actual ADG, kg/d & 0.11 & 0.34 & 0.025 & $<0.001$ \\
ADP-allowable gain - actual ADG, kg/d & 0.34 & 0.57 & 0.025 & $<0.001$ \\
d 0 to 56 & & & & \\
Energy-allowable gain, $\mathrm{kg} / \mathrm{d}$ & 0.64 & 0.82 & 0.020 & $<0.001$ \\
ADP-allowable gain, $\mathrm{kg} / \mathrm{d}$ & 0.82 & 1.03 & 0.019 & $<0.001$ \\
Energy-allowable gain - actual ADG, kg/d & 0.01 & 0.17 & 0.015 & $<0.001$ \\
ADP-allowable gain - actual ADG, kg/d & 0.18 & 0.39 & 0.015 & $<0.001$ \\
\hline
\end{tabular}

${ }^{1}$ Energy- and ADP-allowable gain were predicted based on NRC (2001).

${ }^{2}$ Moderate: $0.66 \mathrm{~kg}$ of DM/d for the first $39 \mathrm{~d}$ followed by one-half of the allotment for $3 \mathrm{~d}$. High: $0.96 \mathrm{~kg}$ of $\mathrm{DM} / \mathrm{d}$ for the first $42 \mathrm{~d}$ followed by one-half of the allotment for $7 \mathrm{~d}$.

MR at various rates (Hill et al., 2016; Rosenberger et al., 2017). In contrast, the efficiency of ME, CP, and ADP utilization in the present study were higher in moderate- versus high-fed calves. The greater feed efficiency may be attributed to higher digestibility of OM, DM, and NDF in moderate-fed calves. We did not measure changes of blood metabolites and hormones in moderate- or high-fed calves. Nevertheless, much evidence from other studies has shown the effects of feeding varying amounts of milk or MR to calves on endocrine and metabolic status (Schäff et al., 2016; Haisan et al., 2018), which might affect calf nutrient utilization and thus its efficiency for growth. Calves fed large versus small amounts of milk or MR had greater plasma concentrations of insulin (Schäff et al., 2016) and insulin-like growth factor (Schäff et al., 2016; Haisan et al., 2018). However, Bach et al. (2013a) showed calves fed a large amount of MR decreased insulin sensitivity. More recent findings (MacPherson et al., 2016), on the contrary, suggested feeding dairy calves more MR would not decrease insulin sensitivity.
Energy- and ADP-allowable ADG were predicted using the young calf model in NRC (2001), with the inputs of calf BW, ambient temperature, and nutrients of MR and starter (Table 4, Figure 2). It was found that actual ADG in calves fed either moderate or high were less than the growth rates allowed by amounts of energy and ADP offered. For instance, actual ADG were 55 and $76 \%$ of predicted energy-allowable ADG from d 0 to 21 , and 78 and $98 \%$ of predicted energyallowable ADG from d 0 to 56 for calves fed high versus moderate. Morrison et al. (2012) reported that achieved ADG were approximately $60 \%$ of predicted ADG when calves were offered MR at the high feeding rate, and that most observed ADG were less than predicted by NRC (2001) after reviewing several studies evaluating feeding rates of MR. The discrepancies between actual ADG and energy- or ADP-allowable ADG (Table 4), in either the first $21 \mathrm{~d}$ or the entire nursery period $(\mathrm{d}$ $0-56)$, were smaller for moderate- versus high-fed calves $(P<0.001)$. Although high-fed calves had higher ADG compared with moderate-fed calves for the first $3 \mathrm{wk}$

Table 5. Performance of calves (d 56-112) as influenced by moderate or high rates of milk replacer fed to the calves preweaning

\begin{tabular}{|c|c|c|c|c|}
\hline \multirow[b]{2}{*}{ Item } & \multicolumn{2}{|c|}{ Preweaning milk replacer ${ }^{1}$} & \multirow[b]{2}{*}{ SEM } & \multirow[b]{2}{*}{$P$-value } \\
\hline & Moderate & High & & \\
\hline Initial BW, kg & 78.1 & 83.8 & 1.37 & 0.014 \\
\hline Initial hip width, $\mathrm{cm}$ & 22.09 & 22.92 & 0.194 & 0.013 \\
\hline $\mathrm{ADG}, \mathrm{kg} / \mathrm{d}$ & 0.99 & 0.91 & 0.016 & 0.011 \\
\hline DMI, kg/d & 2.92 & 3.12 & 0.057 & 0.030 \\
\hline DMI, g per $\mathrm{kg}$ of BW & 28.3 & 28.3 & 0.44 & 0.985 \\
\hline Gain/DMI, kg/kg & 0.335 & 0.307 & 0.0079 & 0.030 \\
\hline Hip width change, $\mathrm{cm}$ & 5.32 & 4.68 & 0.156 & 0.015 \\
\hline
\end{tabular}


in the present study (Table 4; Figure 2), the difference in ADG was small. With more energy and protein provided via feeding more MR, high-fed calves should have had a considerably greater ADG than moderatefed calves. In addition, given the MR $(27 \% \mathrm{CP}$ and $18 \%$ fat) fed to calves at 2 feeding rates, it was shown that the predicted ADP-allowable ADG was greater compared with the predicted energy-allowable ADG (Table 4; Figure 2), and that as mentioned above, calf growth was not limited by dietary energy offered. Thus, protein in the diet preweaning appeared to be excessive, specifically for high-fed calves (Table 4).

Postweaning ADG and hip width change (d 56-112) were greater for moderate-fed calves in the present study, which is consistent with the previous studies (Hill et al., 2016), in which the rate of MR in moderate-fed calves was $0.66 \mathrm{~kg}$ of $\mathrm{DM} / \mathrm{d}$ for $49 \mathrm{~d}$ and was compared with an aggressive MR program with even more MR relative to high in the present study. Korst et al. (2017) compared restricted MR (23\% CP, $17 \%$ fat) feeding $(0.78 \mathrm{~kg}$ of $\mathrm{DM} / \mathrm{d})$ to ad libitum access to MR (>1.1 kg of DM/d) during the first 4 wk of life, preweaning ADG was greater for calves fed ad libitum MR, but BW were similar at $110 \mathrm{~d}$ of age. No structural growth measurement was reported in the study (Korst et al., 2017). As mentioned earlier, nutrient digestibility measured at d 51 to 55 in the present study was greater in moderate- versus high-fed calves; greater nutrient digestibility was indicative of improved rumen development and postweaning digestion in moderate- versus high-fed calves, resulting in greater ADG and hip width change by 4 mo of age.

\section{CONCLUSIONS}

Feeding calves 0.96 versus $0.66 \mathrm{~kg}$ of $\mathrm{DM} / \mathrm{d}$ from a $27 \% \mathrm{CP}, 18 \%$ fat MR resulted in similar ADG and structural growth in the nursery period (d 0-56), but less ADG and structural growth in the grower period (d 56-112). The moderate MR feeding program appeared to better prepare calves for weaning. Efficiency of ME, $\mathrm{CP}$, and $\mathrm{ADP}$ was improved in calves fed MR at a rate of $0.66 \mathrm{~kg}$ of $\mathrm{DM} / \mathrm{d}$. Greater total-tract digestibility of $\mathrm{OM}, \mathrm{DM}, \mathrm{NDF}$, and ADF postweaning in calves fed 0.66 versus $0.96 \mathrm{~kg}$ of $\mathrm{DM}$ from $\mathrm{MR}$ might partially explain why moderate MR feeding was more effective to support growth of dairy calves up to 4 mo of age.

\section{ACKNOWLEDGMENTS}

This research was wholly funded by Provimi North America, a division of Cargill Animal Nutrition.

\section{REFERENCES}

AOAC International. 2000. Official Methods of Analysis. 17th ed. AOAC International, Arlington, VA.

Bach, A., L. Domingo, C. Montoro, and M. Terré. 2013a. Short communication: Insulin responsiveness is affected by the level of milk replacer offered to young calves. J. Dairy Sci. 96:4634-4637.

Bach, A., M. Terré, and A. Pinto. 2013b. Performance and health responses of dairy calves offered different milk replacer allowances. J. Dairy Sci. 96:7790-7797.

Bateman, H. G., II, T. M. Hill, J. M. Aldrich, and R. L. Schlotterbeck. 2009. Effects of corn processing, particle size, and diet form on performance of calves in bedded pens. J. Dairy Sci. 92:782-789.

Chapman, C. E., P. S. Erickson, J. D. Quigley, T. M. Hill, H. G. Bateman II, F. X. Suarez-Mena, and R. L. Schlotterbeck. 2016. Effect of milk replacer program on calf performance and digestion of nutrients with age of the dairy calf. J. Dairy Sci. 99:2740-2747.

Cowles, K. E., R. A. White, N. L. Whitehouse, and P. S. Erickson. 2006. Growth characteristics of calves fed an intensified milk replacer regimen with additional lactoferrin. J. Dairy Sci. 89:48354845.

Dennis, T. S., F. X. Suarez-Mena, T. M. Hill, J. D. Quigley, R. L Schlotterbeck, and L. Hulbert. 2018a. Effect of milk replacer feeding rate, age at weaning, and method of reducing milk replacer to weaning on digestion, performance, rumination, and activity in dairy calves to 4 months of age. J. Dairy Sci. 101:268-278.

Dennis, T. S., F. X. Suarez-Mena, T. M. Hill, J. D. Quigley, R. L. Schlotterbeck, R. N. Klopp, G. J. Lascano, and L. Hulbert. 2018b. Effects of gradual and later weaning ages when feeding high milk replacer rates on growth, textured starter digestibility, and behavior in Holstein calves from 0 to 4 months of age. J. Dairy Sci. 101:9863-9875.

Diaz, M. C., M. E. Van Amburgh, J. M. Smith, J. M. Kelsey, and E. L. Hutten. 2001. Composition of growth of Holstein calves fed milk replacer from birth to 105-kilogram body weight. J. Dairy Sci. 84:830-842.

Dubois, M., K. A. Gilles, J. K. Hamilton, P. A. Rebers, and F. Smith. 1956. Colorimetric method for determination of sugars and related substances. Anal. Chem. 28:350-356.

FASS. 2010. Guide for the Care and Use of Agricultural Animals in Research and Teaching. 3rd ed. FASS Inc., Champaign, IL.

Funaba, M., K. Kagiyama, T. Iriki, and M. Abe. 1997. Duodenal flow of microbial nitrogen estimated from urinary excretion of purine derivatives in calves after early weaning. J. Anim. Sci. 75:19651973.

Gelsinger, S. L., A. J. Heinrichs, and C. M. Jones. 2016. A metaanalysis of the effects of preweaned calf nutrition and growth on first-lactation performance. J. Dairy Sci. 99:6206-6214.

Haisan, J., M. Oba, D. J. Ambrose, and M. A. Steele. 2018. Short communication: The effects of offering a high or low plane of milk preweaning on insulin-like growth factor and insulin-like growth factor binding proteins in dairy heifer calves. J. Dairy Sci. 101:11441-11446.

Hall, M. B. 2009. Determination of starch, including maltooligosaccharides, in animal feeds: comparison of methods and a method recommended for AOAC collaborative study. J. AOAC Int. 92:42-49.

Hill, T. M., H. G. Bateman II, J. M. Aldrich, and R. L. Schlotterbeck. 2009. Optimizing nutrient ratios in milk replacers for calves less than five weeks of age. J. Dairy Sci. 92:3281-3291.

Hill, T. M., H. G. Bateman II, J. M. Aldrich, and R. L. Schlotterbeck. 2010. Effect of milk replacer program on digestion of nutrients in dairy calves. J. Dairy Sci. 93:1105-1115.

Hill, T. M., H. G. Bateman II, J. M. Aldrich, R. L. Schlotterbeck, and K. G. Tanan. 2008. Optimal concentrations of lysine, methionine, and threonine in milk replacers for calves less than five weeks of age. J. Dairy Sci. 91:2433-2442.

Hill, T. M., J. D. Quigley, F. X. Suarez-Mena, H. G. Bateman II, and R. L. Schlotterbeck. 2016. Effect of milk replacer feeding rate and functional fatty acids on dairy calf performance and digestion of nutrients. J. Dairy Sci. 99:6352-6361. 
Hill, T. M., M. J. VandeHaar, L. M. Sordillo, D. R. Catherman, H. G. Bateman II, and R. L. Schlotterbeck. 2011. Fatty acid intake alters growth and immunity in milk-fed calves. J. Dairy Sci. 94:39363948.

Jasper, J., and D. M. Weary. 2002. Effects of ad libitum milk intake on dairy calves. J. Dairy Sci. 85:3054-3058.

Kertz, A. F., and H. Chester-Jones. 2004. Invited Review: Guidelines for measuring and reporting calf and heifer experimental data. J. Dairy Sci. 87:3577-3580.

Khan, M. A., H. J. Lee, W. S. Lee, H. S. Kim, S. B. Kim, K. S. Ki, J. K. Ha, H. G. Lee, and Y. J. Choi. 2007. Pre- and postweaning performance of Holstein female calves fed milk through step-down and conventional methods. J. Dairy Sci. 90:876-885.

Korst, M., C. Koch, J. Kesser, U. Müller, F.-J. Romberg, J. Rehage, K. Eder, and H. Sauerwein. 2017. Different milk feeding intensities during the first 4 weeks of rearing in dairy calves: Part 1: Effects on performance and production from birth over the first lactation. J. Dairy Sci. 100:3096-3108.

MacPherson, J. A. R., H. Berends, L. N. Leal, J. P. Cant, J. MartínTereso, and M. A. Steele. 2016. Effect of plane of milk replacer intake and age on glucose and insulin kinetics and abomasal emptying in female Holstein Friesian dairy calves fed twice daily. J. Dairy Sci. 99:8007-8017.

Morrison, S. J., H. C. F. Wicks, A. F. Carson, R. J. Fallon, J. Twigge, D. J. Kilpatrick, and S. Watson. 2012. The effect of calf nutrition on the performance of dairy herd replacements. Animal 6:909-919.

NRC. 2001. Nutrient Requirements of Dairy Cattle. 7th rev. ed. Natl. Acad. Sci., Washington, DC.

Omidi-Mirzaei, H., M. Khorvash, G. R. Ghorbani, B. Moshiri, M Mirzaei, A. Pezeshki, and M. H. Ghaffari. 2015. Effects of the step-up/step-down and step-down milk feeding procedures on the performance, structural growth, and blood metabolites of Holstein dairy calves. J. Dairy Sci. 98:7975-7981.
Robertson, J. B., and P. J. Van Soest. 1981. The detergent system of analysis and its application to human foods. Pages 123-158 in The Analysis of Dietary Fiber in Food. W. P. T. James and O. Theander, ed. Marcel Dekker, New York, NY.

Rosenberger, K., J. H. C. Costa, H. W. Neave, M. A. G. von Keyserlingk, and D. M. Weary. 2017. The effect of milk allowance on behavior and weight gains in dairy calves. J. Dairy Sci. 100:504-512.

SAS Institute Inc. 2012. Enterprise Guide 5.1. SAS Institute Inc. Cary, NC.

Schäff, C. T., J. Gruse, J. Maciej, M. Mielenz, E. Wirthgen, A. Hoeflich, M. Schmicke, R. Pfuhl, P. Jawor, T. Stefaniak, and H. M. Hammon. 2016. Effects of feeding milk replacer ad libitum or in restricted amounts for the first five weeks of life on the growth, metabolic adaptation, and immune status of newborn calves. PLoS One 11:e0168974.

Sweeney, B. C., J. Rushen, D. M. Weary, and A. M. de Passillé. 2010. Duration of weaning, starter intake, and weight gain of dairy calves fed large amounts of milk. J. Dairy Sci. 93:148-152.

Terré, M., M. Devant, and A. Bach. 2006. Performance and nitrogen metabolism of calves fed conventionally or following an enhancedgrowth feeding program during the preweaning period. Livest. Sci. 105:109-119.

Terré, M., M. Devant, and A. Bach. 2007. Effect of level of milk replacer fed to Holstein calves on performance during the preweaning period and starter digestibility at weaning. Livest. Sci. 110:82-88.

Van Keulen, J. V., and B. A. Young. 1977. Evaluation of acid insoluble ash as a natural marker in ruminant digestibility studies. J. Anim. Sci. 44:282-287.

Van Soest, P. J., J. B. Robertson, and B. A. Lewis. 1991. Methods for dietary fiber, neutral detergent fiber, and nonstarch polysaccharides in relation to animal nutrition. J. Dairy Sci. 74:3583-3597. 